\title{
ACETYLSECO HEMICHOLINIUM-3, A NEW CHOLINE ACETYLTRANSFERASE INHIBITOR USEFUL IN NEUROPHARMACOLOGICAL STUDIES*
}

\author{
E. F. Domino, Margaret E. Mohrman, Ann E. Wilson \\ and V. B. HAARSTAD \\ Michigan Neuropsychopharmacology Research Program, Department of Pharmacology, \\ University of Michigan, Ann Arbor, Michigan and Tulane University, \\ New Orleans, Louisiana
}

(Accepted 22 October 1972)

\begin{abstract}
Summary-Described are the synthesis and some aspects of the pharmacology of acetylseco hemicholinium-3 (acetylseco HC-3), the acetylated open ring analogue of hemicholinium-3 (HC-3). The effects of both compounds were determined in vivo on rat brain acetylcholine (ACh), ${ }^{14} \mathrm{C}$-choline $\left({ }^{14} \mathrm{C}\right.$-Ch) incorporation into ${ }^{14} \mathrm{C}$-acetylcholine $\left({ }^{14} \mathrm{C}\right.$ - $\left.\mathrm{ACh}\right)$ and on one way jump box avoidance and escape behavior in naive and trained rats. In addition, the in vitro effects of both drugs were determined on choline acetyltransferase activity (ChAc) in rat brain.

When given intraventricularly in doses of 1-20 $\mu \mathrm{g}$ both compounds reduced total ACh content in the brain to a maximum of $50 \%$ of normal in 30-60 min. In doses of $20 \mu \mathrm{g}$ intraventricularly, both drugs also reduced ${ }^{14} \mathrm{C}$ - $\mathrm{Ch}$ incorporation into ${ }^{14} \mathrm{C}$-ACh by $84.5 \%$ for acetylseco $\mathrm{HC}-3$ and by $52 \%$ for $\mathrm{HC}-3$.

The in vivo changes of $\mathrm{ACh}$ in the brain were correlated with the behavioral deficits induced in one way shuttle box acquisition and retention. In doses of $20 \mu \mathrm{g}$ total intraventricularly, both compounds produced behavioral deficits which were greater in naive than in trained animals. In vitro, acetylseco $\mathrm{HC}-3$ inhibited ChAc activity with an $I_{50}$ of $1 \times 10^{-3} \mathrm{M}$ with $\mathrm{Ch} 10^{-2} \mathrm{M}$ and acetyl $\mathrm{CoA} 6.4 \times 10^{-4} \mathrm{M}$, while $\mathrm{HC}-3$ had no inhibitory effects. Using rat brain homogenate as the enzyme source and commercial acetyl CoA for kinetic studies, acetylseco HC-3 was shown to be a mixed inhibitor of acetyl CoA and a competitive inhibitor of $C h$.

The in vivo actions of acetylseco $\mathrm{HC}-3$ are consistent with those of a ChAc inhibitor. However, it is necessary to rule out the possibility that the drug may also compete with Ch for its transport across biological membranes like its deacetylated derivative $\mathbf{H C}-3$.
\end{abstract}

The hemicholiniums have been widely investigated since they were first synthesized in 1954 by LONG and SCHUELER. Hemicholinium-3 (HC-3) is the prototype compound of this series. This agent reduces tissue acetylcholine $(\mathrm{ACh})$, possibly by reducing the active transport of choline (Ch) as shown by MACINTOSH (1963) and HoDGKIN and MARTIN (1965). However, other mechanisms such as a shift in Ch metabolism toward phospholipid formation (Gomez, Domino and Sellinger, 1970a,b; Gomez, Sellinger, Santiago and DomiNo, 1971) and production of a false neurotransmitter through acetylation (RODRIGUEZ DE Lores ARNAIZ, Lieber and DE RoberTis, 1970) have been proposed. Schueler (1955) found that $\mathrm{HC}-3$ was the most toxic of some 20 bis-quaternary derivatives studied. $\mathrm{HC}-10$ or acetylseco hemicholinium-3 (acetylseco HC-3) produced a toxicological picture similar to HC-3. SCHUELER assumed that acetylseco HC-3 was hydrolyzed in vivo to HC-3. There was little evidence then that acetylseco HC-3 was pharmacologically different from HC-3.

*Supported in part by USPHS Grant MH-11846 (EFD) and 5T01-GM 00363, Ca 03037 and GM-17124 (VBH). 
The chemical structures of these two compounds are given in Figure 1. Note that HC-3 exists in the hemiacetal form. The fact that "hemiacetal" formation in the ring of HC-3 is not essential for neuromuscular blocking effects (GESLER, LASHER, Hoppe and STECK,

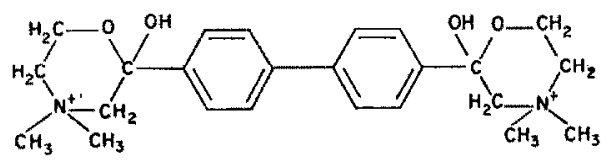

Hemicholinium - 3

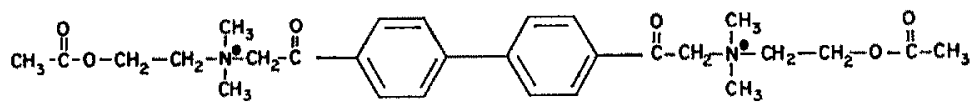

Acetylseco HC-3

Fig. 1. Comparison of structures of acetylseco $\mathrm{HC}-3$ and $\mathrm{HC}-3$.

Note that both compounds are bisquaternary nitrogen derivatives. HC-3 exists as the hemiacetyl ring structure.

1959) and that acetylseco HC-3, the acetate derivative of the opened ring form of HC-3 cannot exist in the hemiacetal form suggests that acetylseco $\mathrm{HC}-3$ might possess different pharmacological actions.

MAGGIO and HAARSTAD (unpublished observations) have reported critical pharmacological differences between HC-3 and acetylseco HC-3 in which inhibition of choline acetyltransferase (acetyl CoA-choline O-acetyltransferase EC2.3.1.6, ChAc) by the latter is especially prominent (DE Balbian Verster, HaARstad and White, 1968, 1969). The present manuscript describes further some of the pharmacological properties of acetylseco HC-3 which indicate it to be an important new tool to inhibit ACh synthesis in the brain when the drug is given intraventricularly.

\section{METHODS}

\section{Chemical synthesis}

The compound, $\alpha, \alpha$-dibromo-4,4'-biacetophenone, which is a precursor for acetylseco HC-3, was prepared according to the method of HAARSTAD and SCHUELER (unpublished observations) which is a modification of the method of LONG and SCHUELER (1954). Acetylseco HC-3 dibromide, [4,4'-diphenylylenebis (2-oxoethylene)] bis [(2-acetoxyethyl) dimethylammonium bromide], was prepared as follows: $0.5 \mathrm{~g}$ of $\alpha, \alpha$-dibromo-4,4'-biacetophenone was dissolved in $50 \mathrm{ml}$ of boiling tetrahydrofuran. The solution was allowed to cool to about $50^{\circ} \mathrm{C}$. Two ml of freshly distilled 2-dimethylaminoethyl acetate was added all at once while the solution was being swirled. A white precipitate began to form almost immediately. The mixture was allowed to stand at room temperature for $7 \mathrm{hr}$. The mixture was filtered through a sintered glass funnel. The precipitate was washed well with tetrahydrofuran, then diethyl ether and dried in a vacuum desiccator over anhydrous calcium chloride. Yield $0.7 \mathrm{~g}(85 \%)$ (m.p., becomes an amber glass at $195^{\circ}$, begins to blacken at $205^{\circ} \mathrm{C}$. (uncorr.); $\lambda_{\max } 305 \mathrm{~nm}$, $\log E_{\max } 4.52$; acetate carbonyl, $5.73 \mu \mathrm{m}$ (s) ketone carbonyl, $5.91 \mu \mathrm{m}$ (s). Anal. Calcd for $\mathrm{C}_{28} \mathrm{H}_{38} \mathrm{Br}_{2} \mathrm{~N}_{2} \mathrm{O}_{2}: \mathrm{C}, 51.08 \% ; \mathrm{H}, 5.82 \% ; \mathrm{N}, 4.25 \%$. Found C, $50.91 \% ; \mathrm{H}, 5.60 ; \mathrm{N}, 3.99 \%$. 
It should be noted that acetylseco HC-3 is prepared analytically pure without the use of a recrystallization step. This has been demonstrated by analyses of several separate preparations. This is to obviate the possibility of transesterification which would lead to the formation of $\mathrm{HC}-3$ itself.

\section{Animal preparations}

Male Holtzman rats in groups of 6-12 were used throughout. Both young rats ( $20-30$ days old) as well as adults ( 90 days and older) were used with intraventricular injection of HC-3 and acetylseco $\mathrm{HC}-3$ in various experiments involving steady state, $\mathrm{ACh}$ depletion and ${ }^{14} \mathrm{C}$-choline $\left({ }^{14} \mathrm{C}\right.$-Ch $)$ incorporation into ${ }^{14} \mathrm{C}$-acetylcholine $\left({ }^{14} \mathrm{C}\right.$ - $\left.\mathrm{ACh}\right)$. All drug doses were calculated as base. Control solutions of equimolar amounts of $\mathrm{NaBr}$ were also used. The young rats were anaesthetized with diethyl ether-air and the bregma exposed to use as a reference point. A puncture point was made on one side approximately $1 \frac{1}{2} \mathrm{~mm}$ posterior and $1 \frac{1}{2} \mathrm{~mm}$ lateral from the bregma to inject either $\mathrm{HC}-3$ or acetylseco $\mathrm{HC}-3$ in the area of the lateral ventricle. A microliter syringe and a needle with a stop were used to inject to a depth of 4-4.5 mm. Rats usually recovered 3-4 min later from anaesthesia and were killed $\frac{1}{2} \mathrm{hr}$ later by guillotine. Brains were removed within $45 \mathrm{sec}$ for various assays. Male Holtzman rats 90 days and older were implanted with polyethylene cannulae as described by Robinson, Hengeveld and de Balbian Verster (1969) and Altaffer, de Balbion VERSTER, HALL, LONG and D'ENCARNACAO (1970) under pentobarbital anaesthesia. Animals were used 7-14 days after cannulation similar to the young rats except that no anaesthetic was involved on the day of the experiment. Sacrifice occurred $10 \mathrm{~min}$ after intraventricular injection of ${ }^{14} \mathrm{C}$-Ch.

\section{Acetylcholine assay}

After sacrifice by decapitation brains were removed, homogenized and ACh extracted by the acidic alcohol method described by STONE (1955) and CROSSLAND (1961). Extracts were bioassayed on the frog rectus abdominus muscle as per DREN and Domino (1968). As suggested by FELDBERG (1945), ACh standards were prepared in alkali-inactivated extracts to control for the presence of sensitizing factors in the brain tissue. Although acetone $(85 \%)-1 \mathrm{~N}$ formic acid $(15 \%)$ has been reported to be a superior extraction procedure (TORU and APRISON, 1966), it was not used in the bioassay experiments reported because in our hands the frog rectus muscle responded less reproducibly. This extraction procedure was used, however, for the radiochemical studies described below.

\section{Choline acetyltransferase assay}

Adult rat brains were used as a source of choline acetyltransferase (ChAc). On the day of the experiment, a rat was decapitated, the brain quickly removed, weighed, and a $10 \%$ homogenate prepared with distilled water. The ChAc assay procedure was a modification by De Balbinn Verster of the method of Schrier and Schuster (1967) and McCaman and HUNT (1965). The final concentration of the buffer substrate was: $0.3 \mathrm{M}$ sodium chloride, $0.01 \mathrm{M}$ choline chloride, $2 \times 10^{-4} \mathrm{M}$ physostigmine, $0.02 \mathrm{M}$ magnesium sulphate, $0.05 \%$ bovine plasma albumin, 0.08M potassium phosphate $(\mathrm{pH} 7.4)$ and $6.2 \times 10^{-1} \mathrm{M}$ acetyl CoA. ${ }^{14} \mathrm{C}$-Acetyl $\mathrm{CoA}$ was mixed with cold acetyl CoA to yield approximately $20,000 \mathrm{dis} / \mathrm{min}$ per incubation tube. Ten $\mu \mathrm{l}$ of the $10 \%$ homogenate ( $1 \mathrm{mg}$ tissue equivalent) were pipetted into each incubation tube. One hundred $\mu \mathrm{l}$ of the substrate were then added with an automatic 
pipetter. The tubes were incubated for $30 \mathrm{~min}$ at $37^{\circ} \mathrm{C}$ after which the reactions were terminated by placing the tubes in a boiling water bath for about $5 \mathrm{~min}$. The reaction mixture was then placed onto $0.5 \times 8.0 \mathrm{~cm}$ columns (diSPo pipets) prepared from prewashed Dowex $1 \times 8$ chloride. The incubation tubes were then washed with 3 consecutive $0.5 \mathrm{ml}$ water washes, each wash being applied to the Dowex column. The effluent was collected directly into scintillation vials, $15 \mathrm{ml}$ of dioxane scintillation fluid $(8.0 \mathrm{~g}$ PPO, $0.1 \mathrm{~g}$ POPOP, $110 \mathrm{~g}$ naphthalene, 11 dioxane) was added to each vial and the samples counted in a Beckman ambient temperature scintillation counter.

Incorporation of ${ }^{14} \mathrm{C}$-choline into ${ }^{14} \mathrm{C}$-acetylcholine

Unanaesthetized adult male Holtzman rats cannulated at least one week previously were used. Drug and control rats were always done together. Ten min after injection of $20 \mu 1$ ${ }^{14} \mathrm{C}-\mathrm{Ch}(1 \mu \mathrm{Ci} ; 61 \mathrm{mCi} / \mathrm{mm})$ alone or simultaneously with acetylseco HC-3 (20 $\mu \mathrm{g}$ base), the rat was decapitated, the brain quickly removed, weighed, and homogenized in acetone: $1 \mathrm{~N}$ formic acid $(85: 15)$. The extraction method of TORU and APRISON (1965) as adapted by Saelens, Allen and Simke (1970) was used. After the separation of the organic and $\mathrm{H}_{2} \mathrm{O}$ extracts, paper electrophoresis as described by POTTER and MURPHY (1967) and SAELENS et al. (1970) was used to separate $\mathrm{Ch}$ and $\mathrm{ACh}$ in the $\mathrm{H}_{2} \mathrm{O}$ extract. The areas were visualized in iodine vapor and the appropriate sections placed into scintillation vials. One $\mathrm{ml}$ $\mathrm{H}_{2} \mathrm{O}$ and $10 \mathrm{ml}$ of the above described dioxane solution were added to each vial. Counting was done in an ambient temperature Beckman scintillation counter.

\section{One way avoidance behavior}

The effects of intraventricular acetylseco HC-3, HC-3, and different equimolar amounts of $\mathrm{NaBr}$ for the two compounds were studied on acquisition and retention of rat one way avoidance behavior. The apparatus used was an adaptation of that used by CALDwELL, Oberleas, Clancy and PraAsad (1970) as described by Tenen (1966). The behavioral parameters were as follows: The conditioned stimulus (CS) was a $5 \mathrm{sec}$ presentation of four $7.5 \mathrm{~W}$ red lights with the simultaneous presentation of an escape ledge. At the end of $5 \mathrm{sec}$, the CS overlapped with a $5 \mathrm{sec}$ unconditioned stimulus (US) that consisted of $1 \mathrm{~mA} 60 \mathrm{~Hz}$ electric shock delivered to the grid floor. When the rat jumped on the ledge, the sequence was terminated. A $30 \mathrm{sec}$ ledge rest period then ensued. If at the end of this time the animal still persisted in sitting on the ledge, it was automatically pushed off by an electromechanical moving wall. Random intertrial intervals were maintained with a mean of $30 \mathrm{sec}$ and a range of 15-60 sec. After intraventricular injection, a 10 min period was allowed before animals were given 50 trials. The entire session lasted about $1 \mathrm{hr}$. Naive animals were given a total of 50 acquisition trials under the drug and discarded. Trained animals were given 50 trials per day for 5 consecutive days to achieve a $90 \%$ avoidance criterion and then used for the drug studies.

\section{RESULTS}

\section{Comparative effects of acetylseco $\mathrm{HC}-3$ and $\mathrm{HC}-3$ on brain acetylcholine}

In view of the fact that quaternary nitrogen derivatives do not readily penetrate the bloodbrain barrier, both $\mathrm{HC}-3$ and acetylseco $\mathrm{HC}-3$ were given intraventricularly to young rats $\frac{1}{2}$ hr prior to sacrifice. In Figure 2 the dose-effect relationships and per cent mortality are shown for groups of 6-10 rats per dose. Acetylseco HC-3 had a wider separation between 


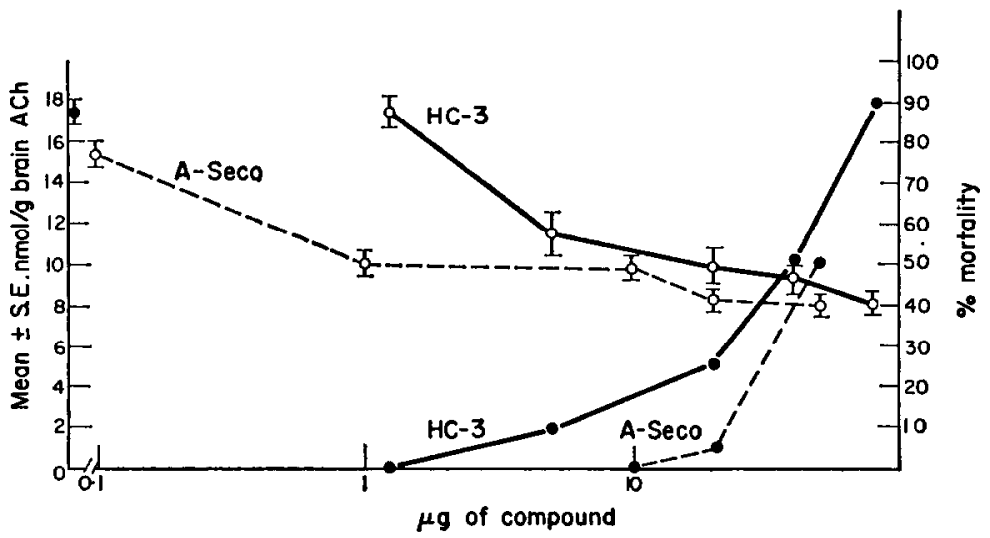

Fig. 2. Dose-effect relations of intraventricular acetylseco HC-3 and HC-3 on rat brain acetylcholine.

On the $x$ axis is plotted the dose as base of the compound listed given intraventricularly. At 0 dose an equimolar amount of sodium bromide to $20 \mu \mathrm{g}$ hemicholinium bromide was given. The mean \pm S.E. for 6-12 rats is shown. Increasing doses of intraventricular acetylseco HC-3 (A-SECO) and HC-3 reduce total brain ACh and increase mortality. Note that acetylseco $\mathrm{HC}-3$ is more potent in reducing brain $\mathrm{ACh}$ and is less toxic. All animals were killed $\frac{1}{2} \mathrm{hr}$ after drug administration.

the dose that lowers ACh in brain and lethality than HC-3. Furthermore, it was much more effective in reducing $\mathrm{ACh}$ at lower doses than $\mathrm{HC}-3$. HC-3 appeared to be a more toxic compound than acetylseco HC-3. With either compound in doses of $50 \mu \mathrm{g}$ intraventricularly there was a 50\% mortality. Animals that received HC-3 exhibited shaking, twitching, rigid posture, sometimes convulsions and respiratory arrest. These effects were especially obvious with larger doses. After acetylseco HC-3 rats did not exhibit any of the characteristic behavior induced by $\mathrm{HC}-3$. In general, they were not very responsive to handling. Both drugs caused over a $50 \%$ loss of ACh with larger doses. After about $1 \mu \mathrm{g}$ of acetylseco $\mathrm{HC}-3$ and $20 \mu \mathrm{g} \mathrm{HC}-3$, no further drop in ACh was produced in rats that survived up to $\frac{1}{2} \mathrm{hr}$ after injection.

\section{Time course of brain acetylcholine depletion following acetylseco $\mathrm{HC}-3$ and $\mathrm{HC}-3$}

In young rats intraventricular acetylseco $\mathrm{HC}-3$ and $\mathrm{HC}-3$ in doses of $20 \mu \mathrm{g}$ total produced similar rates of brain ACh depletion which was maximal 30-60 min after injection. Groups of 8-10 rats were injected and sacrificed at 5, 15, 30 and 60 min later. The effects of acetylseco HC-3 appeared to be somewhat more rapid in onset in lower doses intraventricularly but both drugs showed similar levels of depletion of brain $\mathrm{ACh}$ at $60 \mathrm{~min}$.

\section{Acetylseco $H C-3$ inhibition of choline acetyltransferase activity in vitro}

Rat brain ChAc activity was determined in vitro at different concentrations of acetylseco $\mathrm{HC}-3$ and $\mathrm{HC}-3$ varying from $10^{-7}$ to $10^{-2} \mathrm{M}$. Choline was present at $10^{-2} \mathrm{M}$ and acetyl $\mathrm{CoA}$ at $6.4 \times 10^{-4} \mathrm{M}$. The results of one experiment are shown in Figure 3, plotted as percent of control ChAc activity. IIC-3 had no effect on ChAc activity. In contrast, acetylseco HC-3 was an inhibitor with an $\mathrm{I}_{50}$ of $1 \times 10^{-5} \mathrm{M}$ under these substrate concentrations. When this experiment was repeated with different batches of acetylseco HC-3 and acetyl $\mathrm{CoA}$, the $\mathrm{I}_{50}$ values varied from $5 \times 10^{-6} \mathrm{M}$ to $1 \times 10^{-5} \mathrm{M}$. The fact that several batches of 


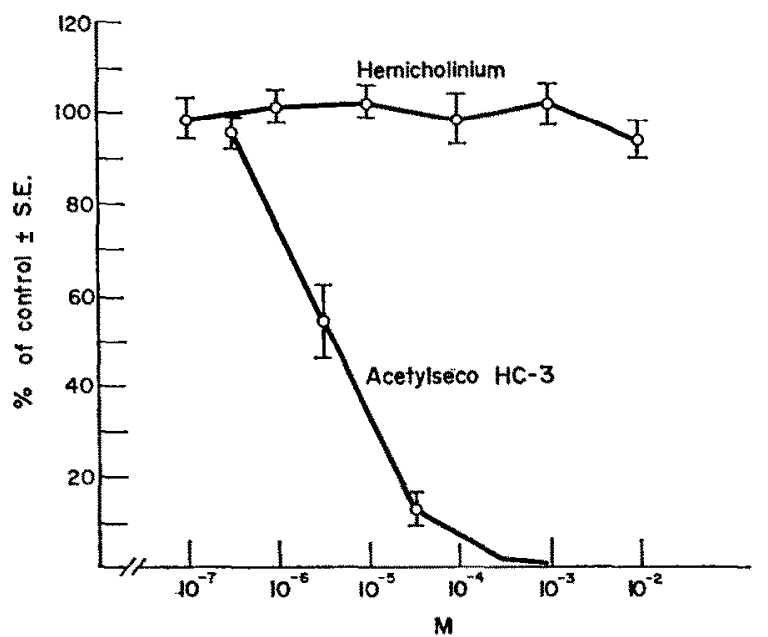

Fig. 3. Comparative effects of acetylseco HC-3 and HC-3 on choline acetyltransferase activity of rat brain homogenate.

On the $x$ axis is given the molar concentration of the 2 compounds and on the $y$ axis the per cent of control ChAc activity. The mean \pm S.E. of 4 separate determinations at each point is given. The substrate concentration for choline was $1 \times 10^{-2} \mathrm{M}$ and for acetyl CoA $6.4 \times 10^{-4} \mathrm{M}$. Note that acetylseco $\mathrm{HC}-3$ is an effective ChAc inhibitor with an $I_{50}$ of $5 \times 10^{-6} \mathrm{M}$ at these substrate concentrations.

acetylseco HC-3 showed similar chemical analyses and caused similar in vivo decreases in brain $\mathrm{ACh}$ when given intraventricularly suggests that the change in $I_{50}$ values is due to different batches of commercial acetyl CoA. This problem has been observed by others using commercial acetyl CoA preparations containing impurities (FonNuM, 1969; SCHUBERTH, 1971). Nevertheless, the results of the present experiments are clear in that acetylseco $\mathrm{HC}-3$ is an inhibitor of ChAc activity but $\mathrm{HC}-3$ is not.

The mode of inhibition of ChAc by acetylseco HC-3 seems complex. DEBALBIAN VERSTER et al. (1968) found that it was competitive with acetyl CoA and non-competitive with choline. Our own data with crude brain enzyme preparations and unpurified commercial acetyl CoA suggests it is mixed. In Figures 4 and 5 are the summarized data of individual experiments in which the reciprocal of varying concentrations of acetyl $\mathrm{CoA}$ and $\mathrm{Ch}$ are plotted against the reciprocal of enzyme activity. These particular Lineweaver-Burk plots were determined using $1 \times 10^{-5} \mathrm{M}$ acetylseco HC-3. Statistical estimates of the $K_{m}$ and $V_{\max }$ were obtained using the computer analysis of WILKINSON (1961). In Figure 4 acetyl $\mathrm{CoA}$ concentrations varied from $3 \cdot 1 \times 10^{-3} \mathrm{M}$ to $3 \cdot 1 \times 10^{-5} \mathrm{M}$. Choline concentration was $10^{-2} \mathrm{M}$. All other substrates in the incubation mixture were as described in the Methods. A $V_{\max }$ for acetyl CoA of $0.28 \pm 0.01 \mu \mathrm{mol} / \mathrm{g}$ per min was obtained without acetylseco $\mathrm{HC}-3$ and $0.19 \pm 0.02 \mu \mathrm{mol} / \mathrm{g}$ per min after the inhibitor. The $K_{m}$ without acetylseco HC-3 was $5.1 \pm 0.65 \times 10^{-4} \mathrm{M}$ and $1.4 \pm 0.34 \times 10^{-3} \mathrm{M}$ with $1 \times 10^{-5} \mathrm{M}$ acetylseco $\mathrm{HC}-3$. These values depict a change caused by the presence of acetylseco HC-3 for both the $V_{\max }$ and the $K_{m}$ of acetyl CoA. The results of an earlier experiment using different batches of drug and substrates also showed changes from normal in both $V_{\max }$ and $K_{m}$ (see Table 1). The inhibition suggested by the use of a crude enzyme preparation and unpurified commercial acetyl $\mathrm{CoA}$ in the presence of acetylseco $\mathrm{HC}-3$ is neither clearly competitive nor non-competitive but might be classified as mixed (WEBB, 1963). 


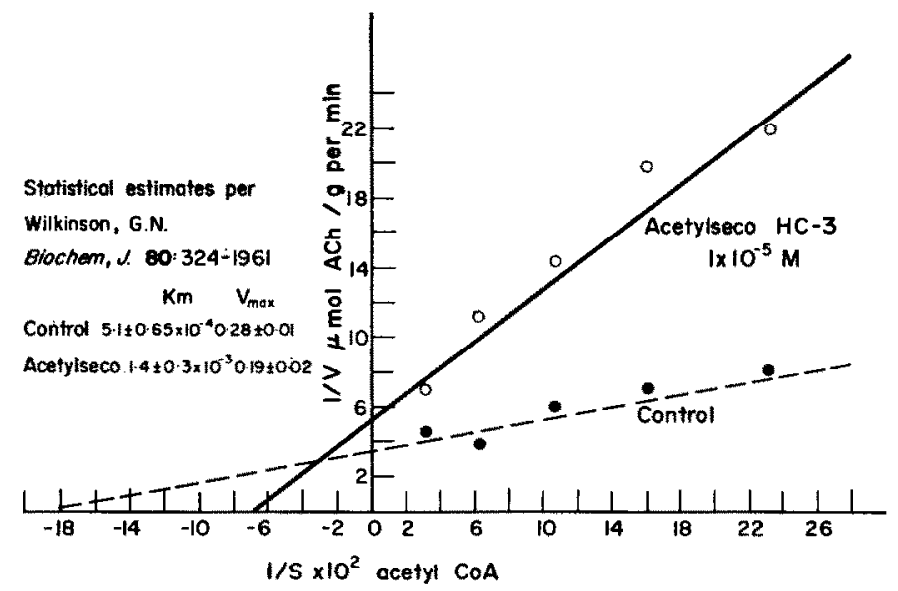

Fig. 4. Lineweaver-Burk plot of the inhibitory effects of acetylseco HC-3 on choline acetyltransferase activity of rat brain homogenate with varying acetyl CoA concentrations and constant choline.

Note that a mixed inhibition is observed. The $K_{m}$ and $V_{\max }$ are given using the statistical estimate technique of WiLkinson (1961) for a range of $7.5 \times 10^{-3}-4.5 \times 10^{-6} \mathrm{M}$. A smaller range is shown for the individual experiment whose data are plotted on this graph.

$\begin{array}{rccc}\text { Statistical estimates per } & & \mathrm{Km} & V_{\text {max }} \\ \text { Wilkinson, G.N. Blochem, J. } & \text { Contral } & 1.3 \pm 0.11 \times 10^{-3} & 0.23 \pm 0.01 \\ 80: 324-1961 & \text { Acetylseco } & 6.9 \pm 1.85 \times 10^{-3} & 0.21 \pm 0.02\end{array}$

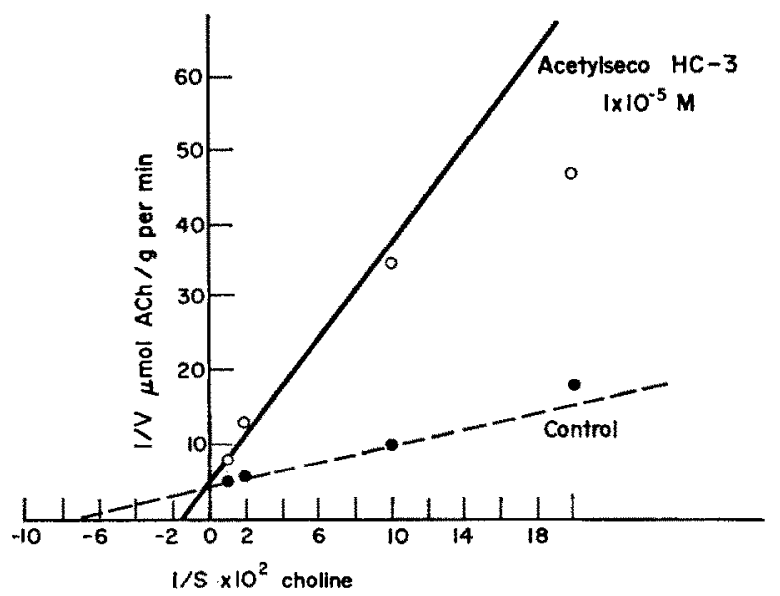

Fig. 5. Lineweaver-Burk plot of the inhibitory effect of acetylseco $\mathrm{HC}-3$ on choline acetyltransferase activity of rat brain homogenate with varying concentrations of choline and constant acetyl CoA.

Note that a competitive inhibition is observed. The $K_{m}$ and $V_{\max }$ are given using the statistical estimate techniques of WILKINson (1961) for a range of $1 \times 10^{-5} \mathrm{M}$. A smaller range is shown for the individual experiment whose data is plotted in this graph. 
Table 1. Kinetic values for mean choline acetyltransferase activity \pm S.E. of rat brain homogenate before and after acetylseco $\mathrm{HC}-3$

\begin{tabular}{|c|c|c|c|c|c|}
\hline \multirow[b]{2}{*}{ Molar range } & \multicolumn{3}{|c|}{ Choline control } & \multicolumn{2}{|c|}{ Acetylseco HC-3 $\left(5 \times 10^{-6} \mathrm{M}\right)$} \\
\hline & & $\begin{array}{l}K_{m}(\mathrm{M}) \\
\pm \text { S.E. }\end{array}$ & $\begin{array}{c}V_{\max } \\
(\mu \mathrm{mol} / \mathrm{g} \text { per } \min ) \\
\pm \text { S.E. }\end{array}$ & $\begin{array}{l}K_{m}(\mathrm{M}) \\
\pm \text { S.E. }\end{array}$ & $\begin{array}{c}V_{\max } \\
(\mu \mathrm{mol} / \mathrm{g} \text { per min }) \\
\pm \mathrm{S} . \mathrm{E} .\end{array}$ \\
\hline $\begin{array}{l}1 \mathrm{M}-10^{-7} \mathrm{M} \\
10^{-3} \mathrm{M}-10^{-5} \mathrm{M} \\
10^{-2} \mathrm{M}-5 \times 10^{-5} \mathrm{M} \\
10^{-2} \mathrm{M}-10^{-5} \mathrm{M}\end{array}$ & $\begin{array}{l}4 \cdot 02 \\
5 \cdot 4 \\
1 \cdot 1 \\
1 \cdot 3\end{array}$ & $\begin{array}{l}\times 10^{-4} \pm 1 \cdot 12 \\
\times 10^{-4} \pm 0 \cdot 74 \\
\times 10^{-3} \pm 0 \cdot 19 \\
\times 10^{-3} \pm 0 \cdot 11\end{array}$ & $\begin{array}{l}0.238 \pm 0.009 \\
0.222 \pm 0.008 \\
0.162 \pm 0.009 \\
0.225 \pm 0.006\end{array}$ & $\begin{array}{l}1.04 \times 10^{-4} \pm 0.31 \\
6.0 \times 10^{-4} \pm 1.15 \\
1.4 \times 10^{-3} \pm 0.35 \\
6.9 \times 10^{-3} \pm 1.85\end{array}$ & $\begin{array}{l}0 \cdot 236 \pm 0.014 \\
0 \cdot 182 \pm 0.012 \\
0 \cdot 119 \pm 0.011 \\
0.206 \pm 0.020\end{array}$ \\
\hline & \multicolumn{3}{|c|}{ Acetyl CoA control } & \multicolumn{2}{|c|}{ Acetylseco HC-3 $\left(5 \times 10^{-6} \mathrm{M}\right)$} \\
\hline $\begin{array}{l}7.5 \times 10^{-3} \mathrm{M}-4.5 \times 10^{-6} \mathrm{M} \\
3.1 \times 10^{-3} \mathrm{M}-3.1 \times 10^{-5} \mathrm{M}\end{array}$ & $\begin{array}{l}3 \cdot 4 \\
5 \cdot 1\end{array}$ & $\begin{array}{l}\times 10^{-4} \pm 0.41 \\
\times 10^{-4} \pm 0.65\end{array}$ & $\begin{array}{l}0 \cdot 388 \pm 0 \cdot 014 \\
0 \cdot 284 \pm 0 \cdot 014\end{array}$ & $\begin{array}{l}4.3 \times 10^{-3} \pm 0.5 \\
1.43 \times 10^{-3} \pm 0.34\end{array}$ & $\begin{array}{l}0.230 \pm 0.008 \\
0.192 \pm 0.017\end{array}$ \\
\hline
\end{tabular}

Lineweaver-Burk analysis of data obtained by varying $\mathrm{Ch}$ from $10^{-2}$ to $10^{-5} \mathrm{M}$ is shown in Figure 5. Acetyl CoA was held constant at $6.4 \times 10^{-4} \mathrm{M}$. A $V_{\max }$ for Ch of $0.23 \pm 0.01$ $\mu \mathrm{mol} / \mathrm{g}$ per min without acetylseco $\mathrm{HC}-3$ and $0.21 \pm 0.02 \mu \mathrm{mol} / \mathrm{g}$ per min with acetylseco HC-3 was obtained. The $K_{m}$ without acetylseco $\mathrm{HC}-3$ was $1.3 \pm 0.11 \times 10^{-3} \mathrm{M}$ and $6.9 \pm 1.9 \times 10^{-3} \mathrm{M}$ with this inhibitor. It would appear that in this particular experiment, and at the molar ranges depicted, competitive inhibition is involved. Several other experiments performed over a period of one year with different batches of acetyl CoA and acetylseco HC-3 produced similar results, as shown in Table 1.

Effect of intraventricular acetylseco $\mathrm{HC}-3$ and $\mathrm{HC}-3$ on ${ }^{14} \mathrm{C}$-choline incorporation into ${ }^{14} \mathrm{C}$-acetylcholine in vivo

As described in the Methods, ${ }^{14} \mathrm{C}$ - $\mathrm{Ch}$ in a dose of $160 \mathrm{nmol}$ and $1 \mu \mathrm{Ci}$ was given intraventricularly to unanaesthetized adult rats with indwelling polyethylene brain cannulae. A time interval of 10 min between injection and decapitation was chosen to minimize the effects of counting recycled ${ }^{14} \mathrm{C}-\mathrm{Ch}$ and because our previous experiments indicated incorporation of at least $5 \%{ }^{14} \mathrm{C}$-Ch into ${ }^{14} \mathrm{C}$-ACh at this time. The effects of acetylseco $\mathrm{HC}-3$ and $\mathrm{HC}-3$ on in vivo incorporation of ${ }^{14} \mathrm{C}$ - $\mathrm{Ch}$ into ${ }^{14} \mathrm{C}$ - $\mathrm{ACh}$ are shown in Figure 6 . The values of at least 6 animals per drug are normalized as per cent change from control. Acetylseco HC-3 drastically reduced ${ }^{14} \mathrm{C}$ - $\mathrm{Ch}$ incorporation into ${ }^{14} \mathrm{C}-\mathrm{ACh}$ to $15 \cdot 5 \pm 1 \cdot 1 \%$ of control. $\mathrm{HC}-3$ in equal amounts $(20 \mu \mathrm{g})$ reduced ${ }^{14} \mathrm{C}$-Ch incorporation to $48 \cdot 0 \pm 9 \cdot 6 \%$. The mean \pm S.E. extractable free pool of ${ }^{14} \mathrm{C}-\mathrm{Ch}$ was $157 \cdot 5 \pm 15.5 \%$ after acetylseco $\mathrm{HC}-3$ and only $118.4 \pm 5.7 \%$ after HC-3. These differences are both statistically significant $(P<0.001$ for acctylscco $\mathrm{HC}-3$ and $P<0.05$ for $\mathrm{HC}-3$ ).

Comparative effects of acetylseco $\mathrm{HC}-3$ and $\mathrm{HC}-3$ on rat one way jump box avoidance and escape behavior

Groups of 8-12 rats were studied on acquisition and performance in a jump box following intraventricular equimolar $\mathrm{NaBr}$ and $20 \mu \mathrm{g}$ intraventricular acetylseco $\mathrm{HC}-3$ and $\mathrm{HC}-3$. Both of these compounds reduced brain ACh to about $50 \%$ of control within $\frac{1}{2}$ hr. Ten minutes after intraventricular injection rats were given 50 trials which lasted about $1 \mathrm{hr}$. Both naive and trained ( $90 \%$ avoidance criterion) animals were run. The data obtained are given in a bar graph format as mean per cent of total response \pm S.E. for each series in 


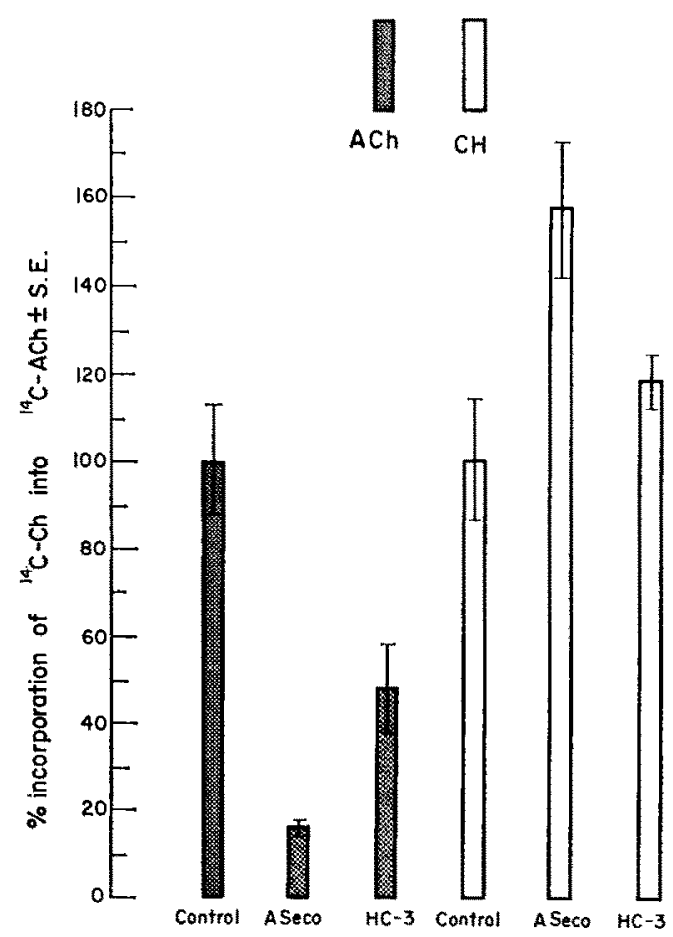

Fig. 6. Effects of acetylseco $\mathrm{HC}-3$ and $\mathrm{HC}-3$ on ${ }^{14} \mathrm{C}$-choline incorporation into ${ }^{14} \mathrm{C}$-acetylcholine in rat brain.

Both drugs $\left(20 \mu \mathrm{g}\right.$ total) as well as ${ }^{14} \mathrm{C}-\mathrm{Ch}(1 \mu \mathrm{Ci}$ total, Specific Radioactivity $61 \mathrm{mCi} / \mathrm{mm})$ were given intraventricularly to groups of 6 adult rats with indwelling polyethylene cannulae. The drug and ${ }^{14} \mathrm{C}$ - $\mathrm{Ch}$ were given simultaneously and the animals sacrificed $10 \mathrm{~min}$ later. Control animals received $20 \mu \mathrm{l}$ intraventricularly of $0.9 \% \mathrm{NaCl}$. The data are normalized so that control levels of ${ }^{14} \mathrm{C}$-Ch incorporation in $\mathrm{ACh}$ represent $100 \%$.

Figure 7. Both acetylseco HC-3 $(P<0.01)$ and HC-3 $(P<0.001)$ significantly reduced acquisition and increased escape responding of naive as well as trained animals. Naive animals were more affected than trained animals. $\mathrm{HC}-3$ produced more behavioral toxicity than acetylseco $\mathrm{HC}-3$ even though both drugs reduced total brain ACh to similar levels. Gross behavioral alterations such as tremors were also more obvious following HC-3.

\section{DISCUSSION}

Several classes of ChAc inhibitors are now known. All have some disadvantages as neuropharmacological tools. Sulphhydryl inhibitors such as indoacetate and p-chloromercuribenzoate are relatively nonspecific (REISBERG, 1957; MANNERVIK and SORBo, 1970). Cysteine is also a ChAc inhibitor but in excessive concentrations (MORRIs, HeBB and BulL, 1966). Several halogen derivatives of $\mathrm{ACh}$ are known to be uncompetitive inhibitors of ChAc in concentrations of $6 \times 10^{-5}$ M (Persson, Larson, Schuberth and Sorbo, 1967; Morris and GrewaAl, 1969; Henderson and Rama Sastry, 1972). Perhaps the best known inhibitors of this enzyme are the styrylpyridine analogues (AlLEN, CARLSON and CAVAlLITO, 1970; Cavallito et al., 1969, 1970a,b; Smith, Cavallito and Foldes, 1967; White and Cavallito, 1970). To this list of ChAc inhibitors one can add acetylseco HC-3. The compound is clearly different from $\mathrm{HC}-3$, although it does share other pharmacological actions 


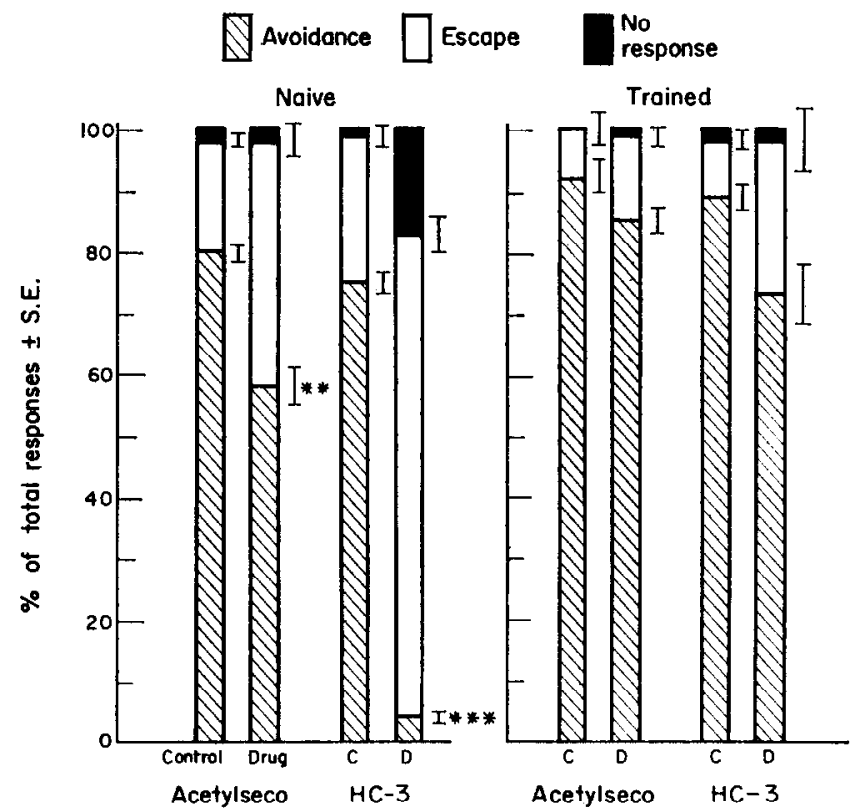

Fig. 7. Comparative effects of acetylseco $\mathrm{HC}-3$ on rat one way avoidance and escape behavior. Both drugs were given intraventricularly in a total dose of $10 \mu \mathrm{g}$ to adult rats with indwelling cannulae. Equimolar amounts of sodium bromide were given for acetylseco HC-3 and HC-3. The hatched bars represent avoidance, the open bars escape, and the solid black bars no response. After each treatment these add to $100 \%$ total responses. The height of each bar represents the mean and the small vertical lines \pm S.E. for avoidance and escape data only. The data from naive animals is to the left and trained animals to the right. Note that both agents depressed acquisition of avoidance more than escape behavior in both naive and well trained animals but that $\mathrm{HC}-3$ is more potent. All the animals were run $10 \mathrm{~min}$ after intraventricular injection for a total of 50 trials which lasted approximately $1 \mathrm{hr}$. Note that both drugs affected naive more than trained animals. Each bar graph represents the mean \pm S.E. of 8-12 animals. A group comparison $t$-test of control and drug treated groups was done. Significant differences of $P$ for avoidance behavior are shown as $* *<0.01$ and $* * *<0.001$.

of HC-3, including reduced toxicity after Ch (MAgGio, 1968; MAgGio and HAarstad, unpublished observations). The fact that acetylseco $\mathrm{HC}-3$ is a bischoline ester makes it susceptible to hydrolysis, although strangely it has not been reported to be a substrate for cholinesterase in vitro.

Studies of the action of intraventricular HC-3 and acetylseco HC-3 on total rat brain $\mathrm{ACh}$ indicate that both reduce $\mathrm{ACh}$, although with different doses, times and lethality. Because of these differences, a study of the in vitro effects of these compounds on rat brain ChAc was deemed important. HC-3 was shown to have no effect while acetylseco HC-3 was found to be a potent inhibitor (Fig. 3), an indication that the two compounds were both reducing brain $\mathrm{ACh}$ through different mechanisms. This does not rule out, however, the possibility that acetylseco $\mathrm{HC}-3$ also affects the transport of $\mathrm{Ch}$ in a manner similar to HC-3. Like HC-3, acetylseco HC-3 is found to markedly alter normal liver metabolism producing fatty liver (MAGGIO and HAARSTAD, unpublished observations). The fact that Ch reverses many of the pharmacological actions of acetylseco HC-3 is further suggestion of an action on Ch transport.

Kinetic studies using Lineweaver-Burk analysis do indicate that acetylseco HC-3 is a competitive inhibitor of Ch. Acetylseco HC-3 also has many similarities with ACh. MAGGIO 
and HAARSTAD (unpublished observations) found acetylseco HC-3 to be a potent parasympathomimetic additive with $\mathrm{ACh}$. $\mathrm{HC}-3$ did not exhibit these properties. Ileum contractions elicited by acetylseco $\mathrm{HC}-3$ were blocked by atropine but not hexamethonium. Studies of base-catalyzed hydrolysis indicate that the ACh moiety of acetylseco $\mathrm{HC}-3$ is similar in chemical reactivity to $\mathrm{ACh}$. If acetylseco $\mathrm{HC}-3$ has similarities to $\mathrm{ACh}$, it could be acting like ACh through substrate inhibition of ChAc. KAITA and GoldBerg (1969) have shown that increasing amounts of $\mathrm{ACh}$ produce competitive inhibition with $\mathrm{Ch}$. If acetylseco HC-3 is occupying the choline site on the enzyme (as ACh would), there would be no acetylation of $\mathrm{Ch}$. There would be no competition for the enzyme site normally occupied by acetyl CoA. Our enzyme kinetics, however, indicate a mixed type of interaction with acetyl CoA. It might be that the greater size of the acetylseco $\mathrm{HC}-3$ molecule is creating a physical hindrance to the attachment of acetyl CoA to the enzyme site.

Of special importance are further studies using purified ChAc to better define the kinetics of inhibition by acetylseco $\mathrm{HC}-3$. The studies reported in this paper should be regarded as preliminary in view of the use of commercially available ${ }^{14} \mathrm{C}$-acetyl $\mathrm{CoA}$ and rat brain homogenate as the enzyme source. In spite of these shortcomings, the data indicate that acetylseco HC-3 may become an important neuropharmacological tool. Results of intraventricular injections of acetylseco $\mathrm{HC}-3$ or $\mathrm{HC}-3$ simultaneously with pulse doses of ${ }^{14} \mathrm{C}-\mathrm{Ch}$ further indicate that acetylseco $\mathrm{HC}-3$ has a more potent effect than HC-3 on incorporation of $\mathrm{Ch}$ into $\mathrm{ACh}$. Again, this does not eliminate the possibility that acetylseco HC-3 affects Ch transport as well as inhibition of ChAc. Its greater potency than HC-3 for reduction of ACh could be due to the combined effects of the two actions. Dramond and KENNEDY (1969) have shown that HC-3 inhibits incorporation of choline into phosphorylcholine. The possibility that acetylseco HC-3 may also do the same must also be studied.

The behavioral effects of intraventricular acetylseco $\mathrm{HC}-3$ as well as $\mathrm{HC}-3$ indicate that these agents are useful in altering brain function in animals. Unexpectedly $\mathrm{HC}-3$ produced greater behavioral toxicity than acetylseco HC-3. Furthermore, tremors were also more obvious after $\mathrm{HC}-3$, suggesting it has further differences in action from acetylseco $\mathrm{HC}-3$.

Of special interest is the fact that 4-(1-naphthylvinyl) pyridine hydrochloride (NVP), one of the potent styrylpyridine derivatives of CAvaLlito et al. $(1969,1970 \mathrm{a}, \mathrm{b})$, had negligible behavioral effects in rats unless massive doses were given i.p. (GoldBerg, SLEDGE, RoBICHAND and DUBINSKY, 1972). Of course, this may have been because NVP does not readily penetrate the blood-brain barrier. In the present study acetylseco HC-3 was given intraventricularly to avoid its obvious peripheral effects when given parenterally. Further studies comparing intraventricular NVP and acetylseco HC-3 on various animal behaviors and possible antagonism by $\mathrm{Ch}$ would be of considerable interest.

Acknowledgements-The authors would like to acknowledge the efforts of Mr. MichaEL LUTz with the behavioral experiments reported.

\section{REFERENCES}

Allen, R. C., Carlson, G. L. and Cavallito, C. J. (1970). Choline-acetyltransferase inhibitors. Physicochemical properties in relation to inhibitory activity of styrylpyridine analogs. J. med. Chem. 13:909-912.

Altaffer, F. B., de Balbian Verster, F., Hall, S., Long, C. J. and D'EnCarnacao, P. (1970). A simple and inexpensive cannula technique for chemical stimulation of the brain. Physiol. Behav. 5: 119-121.

Caldwell, D. F., Oberleas, D., Clancy, J. J. and PraAsad, A. S. (1970). Behavioral impairment in adult rats following acute zinc deficiency. Proc. Soc. exp. Biol. Med. 133: 1417-1421.

Cavallto, C. J., Whrte, H. L., Yun, H. S. and Foldes, F. F. (1970a). Inhibitors of choline acetyltransferase. In: Drugs and Cholinergic Mechanisms in the CNS (Henbron, E. and WinTER, A., Eds.), pp. 97116. Forsvarets Forsknings anstalt, Stockholm. 
Cavallito, C. J., Yun, H. S., Kaplan, T., Smith, J. C. and Foldes, F. F. (1970b). Choline acetyltransferase inhibitors. Dimensional and substituent effects among styrylpyridine analogs. J. med. Chem. 13: 221-224.

Cavallito, C. J., Yun, H. S., SMith, J. C. and Foldes, F. F. (1969). Choline acetyltransferase inhibitors. Configurational and electronic features of styrylpyridine analogs. I. med. Chem. 12: 134-138.

Crossland, J. (1961). Biologic estimation of acetylcholine. Meth. med. Res. 9: 125-129.

de Balbian Verster, F., HaARstad, V. B. and White, E. C. (1968). Inhibition of brain choline acetylase by acetylsecohemicholinium. Pharmacologist 10: 223.

de Balbian Verster, F., HaArstad, V. B. and White, E. C. (1969). Mechanism of action of choline acetylase. Pharmacologist 11: 291.

DiAMOND, I. and KenNEDY, E. P. (1969). Carrier-mediated transport of choline into synaptic nerve endings. J. biol. Chem. 244: 3258-3263.

Dren, A. T. and Domino, E. F. (1968). Effects of hemicholinium (HC-3) on EEG activation and brain acetylcholine in the dog. J. Pharmac. exp. Ther. $161: 141-154$.

Feldberg, W. (1945). Present views on the mode of action of acetylcholine in the central nervous system. Physiol. Rev. 25: 596-642.

FonNum, F. (1969). Radiochemical micro assays for the determination of choline acetyltransferase and acetylcholinesterase activities. Biochem. J. 115: $465-472$.

Gesler, R. M., LAsher, A. V., Hoppe, J. O. and Steck, E. A. (1959). Further studies on the site of action of the neuromuscular blocking agent 3,6-bis (3-diethylaminopropoxy)pyridazine bismethiodide. $J$. Pharmac. exp. Ther. 125: 323-329.

Goldberg, M. E., Sledge, K., Robichand, R. C. and Dubinsky, B. (1972). A comparative study of the behavioral effects of scopolamine and 4-(1-naphthylvinyl) pyridine hydrochloride (NVP) on inhibition of choline acetyltransferase. Psychopharmacologia 23: 34-47.

GomeZ, M. V., Domino, E. F. and Sellinger, O. Z. (1970a). Effect of hemicholinium-3 (HC-3) on choline distribution in vivo in the canine caudate nucleus. Biochem. Pharmac. 19: 1753-1760.

Gomez, M. V., Domino, E. F. and Sellinger, O. Z. (1970b). Effects of hemicholinium-3 on the in vivo formation of cerebral phosphatidylcholine. Biochim. biophys. Acta 202: 153-167.

Gomez, M. V., Sellinger, O. Z., Santiago, J. and Domino, E. F. (1971). Selective regional stimulation by hemicholinium-3 of the formation of cerebral cytidine diphosphocholine in vivo. Int. J. Neurosci. 2: 145-150.

Henderson, G. I. and Rama SASTRy, B. V. (1972). Rat brain choline acetyltransferase (ChA): Enzyme mechanism and inhibition by iodo- and bromoacetylcholines (IACh, BrACh). Fedn Proc. Fedn Am. Socs exp. Biol. 31 : 516.

Hodgkin, A. L. and MArtin, K. (1965). Choline uptake by giant axons of Loligo. J. Physiol., Lond. 197: 26-27.

KaITA, A. A. and GoldberG, A. M. (1969). Control of acetylcholine synthesis-The inhibition of choline acetyltransferase by acetylcholine. J. Neurochem. 16: 1185-1191.

Long, J. P. and Schueler, F. W. (1954). A new series of cholinesterase inhibitors. J. Am. pharm. Ass. (Sci. Edn) 43: 79-86.

MacIntosh, F. C. (1963). Synthesis and storage of acetylcholine in nervous tissue. Can. J. Biochem. Physiol. 41: $2555-2571$.

Maggro, M. B. (1968). Pharmacology of acetylseco hemicholinium. Fedn Proc. Fedn Am. Socs exp. Biol. 27: 306.

MANNERVIK, B. and SORBo, B. (1970). Inhibition of choline acetyltransferase from bovine caudate nucleus by sulfhydryl reagents and reactivation of the inhibited enzyme. Biochem. Pharmac. 19: 2509-2516.

MCCAMAN, R. E. and HUNT, J. M. (1965). Microdetermination of choline acetylase in nervous tissue. $J$. Neurochem. 12: 253-259.

Morris, G. and GrewaAL, D. S. (1969). Halogen substituted derivatives of acetylcholine as inhibitors of choline acetyltransferase. Life Sci. 8: 511-516.

MorRis, D., HebB, C. O. and BuLL, G. (1966). Inhibition of choline acetyltransferase by excess cysteine. Nature, Lond. 209: 914-915.

Persson, B. O., Larson, L., Schuberth, J. and Sorbo, B. (1967). 3-Bromoacetonyltrimeterylammonium bromide, a choline acetylase inhibitor. Acta chem. scand. $21: 2283-2284$.

PotTER, L. T. and MURPHY, W. (1967). Electrophoresis of acetylcholine, choline and related compounds. Biochem. Pharmac. 16: 1386-1388.

ReISBERG, R. B. (1957). Properties and biological significance of choline acetylase. Yale J. Biol. Med. 29: $403-435$.

Robinson, C. A., Hengeveld, C. A. and de Baldian Verster, F. (1969). Improved polyethylene cannulation techniques. Physiol. Behav. 4: 123-124.

Rodriguez de Lores Arnaiz, G., Lieber, L. M. and De Robertis, E. (1970). Neurochemical and structural studies on the mechanism of action of hemicholinium-3 in central cholinergic synapses. $J$. Neurochem. 17: $221-229$. 
Sarlens, J. K., Allen, M. P. and Simke, J. P. (1970). Determination of acetylcholine and choline by an enzymatic assay. Archs int. Pharmacodyn. Thér. 186: 279-286.

SCHRIER, B. K. and Shuster, L. (1967). A simplified radiochemical assay for choline acetyltransferase. $J$. Neurochem. 14: 977-985.

SCHUBERTH, J. (1971). Measurement of choline acetylase. In: Methods of Biochemical Analysis-Analysis of Biogenic Amines and Their Related Enzymes (GLICK, D., Ed.), pp. 275-296. Interscience-Wiley, New York.

SchueLer, F. W. (1955). A new group of respiratory paralyzants. I. The "hemicholiniums". J. Pharmac. exp. Ther. 155: 127-143.

Smrth, J. C., Cavallito, C. J. and Foldes, F. F. (1967). Choline acetyltransferase inhibitors: A group of styryl-pyridine analogs. Biochem. Pharmac. 16: 2438-2441.

STONE, W. E. (1955). Acetylcholine in the brain. I. "Free", "bound" and total acetylcholine. Archs Biochem. Biophys. 59: 181-192.

TenEN, S. S. (1966). An automated one-way avoidance box for the rat. Psychonom. Sci. 6: 407-408.

TORU, M. and APRISON, M. H. (1966). Brain acetylcholine studies: A new extraction procedure. J. Neurochem. 13: $1533-1544$.

WeBB, J. L. (1963). Enzyme and Metabolic Inhibitors, Vol, 1, pp. 1-949. Academic Press, New York.

Whrte, H. L. and CAvilurro, C. J. (1970). Photoisomerization of styrylpyridine analogues in relation to choline acetyltransferase and cholinesterase inhibition. Biochim. biophys. Acta 206: 242-251.

Wruxinson, G. N. (1961). Statistical estimations in enzyme kinetics. Biochem. J. 80: 324-332. 